\title{
THE EFFECTS OF STUDENTS' PERCEPTION ON TEACHER PERFORMANCE AND LEARNING MOTIVATION TOWARDS STUDENTS' ACHIEVEMENTS
}

\author{
Nur Aeni ${ }^{1}$ \\ Supadi ${ }^{2}$ \\ Universitas Indraprasta PGRI \\ Jl. Nangka No. 58, Tanjung Barat, South Jakarta 12530 \\ e-mail: nureaniazzah@gmail.com ${ }^{1}$ \\ e-mail: supadi@unindra.ac.id ${ }^{2}$
}

\begin{abstract}
This research is a kind of survey and aims to determine and analyze the effects of students' perception on teacher performance and learning motivation towards students' achievement in English empirically. The object population of this research is private junior high students in Indramayu. The sample was gained through simple random sampling. The data collection is done by questionnaire for independent variables and teachers' file mid-term test for the dependent variable. The gained data were analyzed by using the correlation technique and multiple regressions. This research is looking for 1) There are any significant effects of students' perception on teacher performance and learning motivation jointly towards students' achievement in English. It is proved by Sig. $=0.000<0.05$ and $F_{o}=49.077$; 2) There is a significant effect of students' perception on teacher performance towards students' achievement in English subject. It is proved by Sig. $=0.000<0.05$ and $t_{0}=5.009 ; 3$ ) There is a significant effect of learning motivation towards students' achievement in English subject. It is proved by and Sig. $=0.000<0.05$ and $\mathrm{t}_{\mathrm{o}}=6.773$. It means that the students' achievement in English is sufficiently influenced by students' perception of teacher performance and learning motivation.
\end{abstract}

Keywords: Students' Perception; Teacher Performance; Learning Motivation; Students Achievement.

\begin{abstract}
Abstrak: Penelitian ini adalah jenis survei dan bertujuan untuk mengetahui dan menganalisis secara empiris pengaruh persepsi siswa terhadap kinerja guru dan motivasi belajar terhadap prestasi siswa dalam mata pelajaran bahasa Inggris. Populasi objek penelitian ini adalah siswa SMP swasta di Indramayu. Sampel diperoleh melalui sample random sampling. Pengumpulan data dilakukan dengan kuesioner untuk variabel independen dan tes jangka menengah guru untuk variabel dependen. Data yang diperoleh dianalisis dengan menggunakan teknik korelasi dan regresi berganda. Hasil penelitian ini adalah: 1) Ada pengaruh yang signifikan persepsi siswa terhadap kinerja guru dan motivasi belajar secara bersama-sama terhadap prestasi belajar siswa dalam mata pelajaran bahasa Inggris. Itu dibuktikan oleh Sig. = 0,000 $<0,05$ dan Fo = 49,077; 2) Ada pengaruh signifikan persepsi siswa terhadap kinerja guru terhadap prestasi belajar siswa dalam mata pelajaran bahasa Inggris. Itu dibuktikan oleh Sig. =0,000<0,05 dan untuk = 5,009; 3) Ada pengaruh yang signifikan dari motivasi belajar terhadap prestasi siswa dalam mata pelajaran bahasa Inggris. Itu dibuktikan oleh dan Sig. $=0,000<0,05$ dan untuk = 6,773. Ini berarti bahwa prestasi siswa dalam mata pelajaran bahasa Inggris cukup dipengaruhi oleh persepsi siswa tentang kinerja guru dan motivasi belajar.
\end{abstract}

Kata Kunci: Persepsi Siswa, Kinerja Guru, Motivasi Belajar, Prestasi Siswa.

\section{Introduction}

Education is one of the necessities of human life. A human being must seek knowledge through education and learn to get the norms and values in the running life. According to Agustina et al. (2006), to educate human life, it is needed to improve, change the knowledge, skills, attitude, and behavior of a person or group through the educational process with guidance, teaching, and research activities. In the teaching and learning process, teachers and students are relating to each other. Teacher performance can affect students' achievement in school. Students can perceive teacher competence by looking at the way teachers teach and the materials or media that teachers use in teaching. Student's perceptions can be positive or negative. It depends on how they accept the material of the lesson that teachers provided. 


\section{INFERENCE: Journal of English Language Teaching}

Vol. 3, No. 2, August - November 2020

p-ISSN: 2615-8671

e-ISSN: 2615-868X

Teacher performance is the teacher's work in carrying out his duties and responsibilities in educational institutions to achieve educational goals (Baharuddin \& Zakaria, 2018). Besides, Mulyasa (2007) stated the teacher performance could be measured through indicators based on main competencies, namely pedagogical competence, personality competence, social competence, and professional competence. An ideal teacher should master the four teacher competencies and acceptable physical appearances (Metimukarrama, 2018). The teacher, as a learning resource, has a significant role (Irianto, 2011; Kusuma, 2017; Sinambela, 2019). Teachers are obliged to deliver course materials to students and teachers and try to change students' behavior following the expected goals. Therefore, there are activities in the teaching process to guide students to develop, practice the skills, and develop academic skills, including enhancing their foreign language. In the learning process, motivating the students in learning is high tendency towards something that arises because of the need to perceive or not perceive or desire certain things. The students' motivation is an essential issue in education, particularly in owning to the importance of academic performance in their professional life (Emda, 2017; Lestari, 1999; Orhan Özen, 2017). In this regard, the concept of motivation is considered as a crucial factor that affects human behavior and performance (Turan, 2015). Motivation is the process of energizing, directing, and providing action to achieve certain goals (Brophy, 2013; Wentzel, 2014).

Furthermore, motivation is usually defined as the processes that stimulate our behaviour or arouse us to act. In particular, Lin (2012) describes motivation as intrinsic desires that are already present in the individual or reflected in the individual while acquiring new information and learning. Harmer (2010:66) also declares that motivation received distinction is made between intrinsic and extrinsic motivation from inside and outside. Moreover, Schunk, Pintrich, \& Meece (2014) suggested that motivation can influence the learning process from previously learned skills, strategies, and behaviors.

Based on the theoretical foundation above, the teacher's performance is a need. The competent teacher should be able to stimulate the students in learning and developing student's English skills. Teachers must creatively deliver lessons, so students have passion and anxiety to learn the English language. Then, teachers as educators are obliged to help students gain their motivation in learning and raise their confidence to practice learning English, not only inside the classroom but also in their daily lives. In this study, the researcher assumes a positive influence of students' perception on teacher performance and learning motivation towards students' English achievement.

\section{Method}

The method used in this research is a survey method with analysis of the regression. The researcher directly visits the object research and provide the research instruments such as questionnaires. This method is used to indicate the influence between variables; variable $X_{1}$ as the first independent variable (student' perception on teacher performance) and variable $\mathrm{X}_{2}$ as the second independent variable (Learning Motivation), which have interconnected and influenced the variable $\mathrm{Y}$ as the dependent variable (Student's English achievement). To make it clearly and easily to understand the concept, here is the form of research design can be seen in Figure 1:

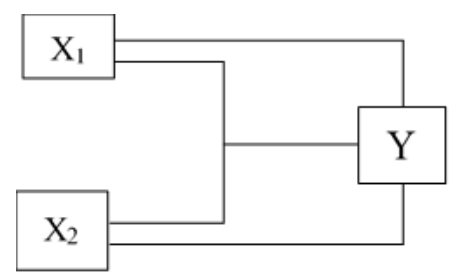

Figure 1. Research design

$$
\begin{array}{ll}
\text { Note: } & \\
\mathrm{X}_{1} & =\text { Students' Perception of Teacher Performance } \\
\mathrm{X}_{2} & =\text { Learning Motivation } \\
\mathrm{Y} & =\text { Student's Achievement in English Subject }
\end{array}
$$

The prerequisite tests will be done to determine whether the collected data is worthy enough to be analyzed later using a statistical tool. The prerequisite tests are the normality test and linearity test. Data 
INFERENCE: Journal of English Language Teaching

Vol. 3, No. 2, August - November 2020

p-ISSN: 2615-8671

e-ISSN: 2615-868X

analysis was conducted using the SPSS application. After processing data, then analyze the independent variables' effect towards the dependent variable using multiple regression linier analysis model that has been processed by the SPSS program. This model was chosen because the researchers wanted to determine the influence of independent variables on the dependent variable and risk factors for the dependent variable's independent variables.

\section{Research Findings and Discussion}

Result of Normality Test

A normality test was conducted in order to identify whether the data were distributed normally or not. The result of the normality test was presented in Table 1.

Table 1. The Result of Normality Test

\begin{tabular}{|c|c|c|c|c|}
\hline \multicolumn{5}{|c|}{ One-Sample Kolmogorov-Smirnov Test } \\
\hline & & $\begin{array}{l}\text { Student's Perception on } \\
\text { Teacher Performance }\end{array}$ & $\begin{array}{l}\text { Learning } \\
\text { Motivation }\end{array}$ & $\begin{array}{c}\text { Student's Achievement in } \\
\text { English Subject }\end{array}$ \\
\hline $\begin{array}{l}\text { N } \\
\text { Normal } \\
\text { Parameters } \\
\text { Most Extreme } \\
\text { Differences } \\
\text { Kolmogorov-Sr } \\
\text { Asymp. Sig. (2 }\end{array}$ & $\begin{array}{l}\text { Mean } \\
\text { Std. Deviation } \\
\text { Absolute } \\
\text { Positive } \\
\text { Negative } \\
\text { ov Z } \\
\text { ed) }\end{array}$ & $\begin{array}{c}218 \\
78.29 \\
11.865 \\
.076 \\
.048 \\
-.076 \\
1.125 \\
.159\end{array}$ & $\begin{array}{c}218 \\
71.68 \\
11.280 \\
.036 \\
.030 \\
-.036 \\
.535 \\
.937\end{array}$ & $\begin{array}{c}218 \\
76.36 \\
6.414 \\
.079 \\
.079 \\
-.053 \\
1.173 \\
.128\end{array}$ \\
\hline
\end{tabular}

According to the criteria of the program, the set of data will be classified as normal if the $p$-value (significance/Sig.) more than (>0.05). As a consequence, $\mathrm{H}_{0}$ is accepted, which means sample data is distributed normally.

\section{Result of Linearity Test}

A linearity test was conducted in order to identify whether both variables had a linear connection or not. The result of the linearity test was presented in Table 2 and Table 3.

Table 2. Linearity Test Result of Regression Line at $\mathrm{X}_{1}$ towards $\mathrm{Y}$.

\begin{tabular}{|c|c|c|c|c|c|c|c|}
\hline \multicolumn{8}{|c|}{ ANOVA Table } \\
\hline & & & Sum of Squares & Df & Mean Square & $\mathrm{F}$ & Sig. \\
\hline \multirow{5}{*}{$\begin{array}{l}\text { Student's Achievement in } \\
\text { English Subject * } \\
\text { Student's Perception on } \\
\text { Teacher Performance }\end{array}$} & \multirow{4}{*}{\multicolumn{2}{|c|}{$\begin{array}{ll}\text { Between } & \text { (Combined) } \\
\text { Groups } & \text { Linearity } \\
& \text { Deviation from Linearity } \\
\text { Within Groups }\end{array}$}} & 3132.625 & 47 & \multirow{5}{*}{$\begin{array}{c}66.652 \\
1490.477 \\
35.699 \\
34.093\end{array}$} & \multirow{5}{*}{$\begin{array}{c}1.955 \\
43.718 \\
1.047\end{array}$} & \multirow{5}{*}{$\begin{array}{l}.001 \\
.000 \\
.405\end{array}$} \\
\hline & & & 1490.477 & 1 & & & \\
\hline & & & 1642.148 & 46 & & & \\
\hline & & & 5795.746 & 170 & & & \\
\hline & Total & & 8928.372 & 217 & & & \\
\hline
\end{tabular}

Table 2 shows that Sig. Value from Deviation from Linearity column is 0.405 . It means that the value is higher than 0.05 . As a consequence, $\mathrm{H}_{0}$ is accepted, and automatically $\mathrm{H}_{1}$ is rejected. In other words, the regression line, which indicates the effects of student's perception on teacher performance $\left(\mathrm{X}_{1}\right)$ towards student's achievement in English subject (Y), is linear. 
INFERENCE: Journal of English Language Teaching

Vol. 3, No. 2, August - November 2020

p-ISSN: 2615-8671

e-ISSN: 2615-868X

Table 3. Linearity Test Result of Regression Line at $\mathrm{X}_{2}$ towards $\mathrm{Y}$.

\begin{tabular}{|c|c|c|c|c|c|c|c|}
\hline \multicolumn{8}{|c|}{ ANOVA Table } \\
\hline & & & $\begin{array}{l}\text { Sum of } \\
\text { Squares }\end{array}$ & Df & $\begin{array}{l}\text { Mean } \\
\text { Square }\end{array}$ & $\mathrm{F}$ & Sig. \\
\hline \multirow{5}{*}{$\begin{array}{l}\text { Student's } \\
\text { Achievement in } \\
\text { English Subject * } \\
\text { Learning Motivation }\end{array}$} & & (Combined) & 3266.895 & 50 & 65.338 & 1.927 & .001 \\
\hline & Between & Linearity & 2083.262 & 1 & 2083.262 & 61.451 & .000 \\
\hline & Groups & Deviation from Linearity & 1183.633 & 49 & 24.156 & .713 & .917 \\
\hline & Within Groups & & 5661.477 & 167 & 33.901 & & \\
\hline & Total & & 8928.372 & 217 & & & \\
\hline
\end{tabular}

Based on Table 3, the Sig. Value from Deviation from Linearity column is 0.917 . It means that the value is higher than 0.05. As a consequence, $\mathrm{H}_{0}$ is accepted, and automatically $\mathrm{H}_{1}$ is rejected. In other words, the regression line, which indicates the effects of student's learning motivation $\left(\mathrm{X}_{2}\right)$ towards student's achievement in English subject (Y), is linear.

Testing of Hypothesis

The hypothesis testing is made as the provision written in advance. The result appears in Table 4, Table 5, and Table 6 as follows:

Table 4. Model Summary: R and R Squared

Model Summary

\begin{tabular}{|l|r|r|r|c|}
\hline Model & $\mathrm{R}$ & $\mathrm{R}$ Square & \multicolumn{1}{|c|}{$\begin{array}{c}\text { Adjusted R } \\
\text { Square }\end{array}$} & $\begin{array}{c}\text { Std. Error of the } \\
\text { Estimate }\end{array}$ \\
\hline 1 & $.560^{\mathrm{a}}$ & .313 & .307 & 5.340 \\
\hline
\end{tabular}

a. Predictors: (Constant), Learning Motivation, Student's Perception of

Teacher Performance

Table 5. Analysis of Variance

ANOVA

\begin{tabular}{|c|c|c|c|c|c|}
\hline Model & Sum of Squares & Df & Mean Square & $\mathrm{F}$ & Sig. \\
\hline Regression & 2798.483 & 2 & 1399.242 & 49.077 & $.000^{\mathrm{b}}$ \\
\hline Residual & 6129.888 & 215 & 28.511 & & \\
\hline Total & 8928.372 & 217 & & & \\
\hline
\end{tabular}

a. Dependent Variable: Student's Achievement in English Subject

b. Predictors: (Constant), Learning Motivation, Student's Perception of Teacher Performance

Table 6. Coefficients of Regression and Partial Significance Test

Coefficients

\begin{tabular}{|c|c|c|c|c|c|c|}
\hline \multirow{2}{*}{\multicolumn{2}{|c|}{ Model }} & \multicolumn{2}{|c|}{$\begin{array}{l}\text { Unstandardized } \\
\text { Coefficients }\end{array}$} & $\begin{array}{l}\text { Standardized } \\
\text { Coefficients }\end{array}$ & \multirow[t]{2}{*}{$\mathrm{T}$} & \multirow[t]{2}{*}{ Sig. } \\
\hline & & $\mathrm{B}$ & Std. Error & Beta & & \\
\hline \multirow{3}{*}{1} & (Constant) & 47.595 & 2.953 & & 16.117 & .000 \\
\hline & $\begin{array}{l}\text { Student's Perception on } \\
\text { Teacher Performance }\end{array}$ & .160 & .032 & .295 & 5.009 & .000 \\
\hline & Learning Motivation & .227 & .034 & .399 & 6.773 & .000 \\
\hline
\end{tabular}

a. Dependent Variable: Student's Achievement in English Subject

\section{The Result of Regression Analysis}

Based on the results of statistical calculations in table 6 above, obtained the multiple regression equation as follows: 
a. $\hat{Y}=47.595+0,160 \mathrm{X}_{1}+0,227 \mathrm{X}_{2}$

b. $\hat{Y}^{*}=0,295 \mathrm{X}^{*}{ }_{1}+0,399 \mathrm{X}_{2}^{*}$

Which:

$$
Y^{*}=\frac{Y-\bar{Y}}{S_{y}} \text { dan } \bar{X}^{*}=\frac{X-\bar{X}}{S_{x}}
$$

The first equation is the raw data, or data $\mathrm{X}_{1}, \mathrm{X}_{2}$, and $\mathrm{Y}$ from the field data. The second equation is the equation in which all variables have been transformed into standard data, i.e., every data in each variable is reduced by its average and then divided by its standard deviation. From this regression equation, it can be directly stated that learning motivation is higher than the effect of students' perceptions on teacher performance towards students' achievement in English language subjects. The Beta value shows that the Standardized $\mathrm{X}_{2}$ variable is greater than the Beta value on the Standardized $\mathrm{X}_{1}$ variable, which is 0.399 > 0.295 .

\section{Correlation and Coefficient of Determination}

Then, the correlation result of those variables was stated in Table 7:

Table 7. Zero-order, Partial, and Part Correlation

\begin{tabular}{|rl|r|r|r|}
\hline Model & \multicolumn{3}{|c|}{ Correlations } \\
\cline { 3 - 5 } & & Zero-order & \multicolumn{1}{|c|}{ Partial } & \multicolumn{1}{c|}{ Part } \\
\hline \multirow{2}{*}{1} & (Constant) & & & \\
& Student's Perception on Teacher & .409 & .323 & .238 \\
& Performance & & .419 & .383 \\
\hline & Learning Motivation & .483 & .43
\end{tabular}

Table 7 shows that the correlation between students' perceptions of teacher performance (X1) towards students' achievement in English subject (Y) is 0.409. It means the correlation degree of the variable is sufficient. Then, the coefficient of partial correlation showed a smaller number, which is 0.323 . This number is the score of coefficient correlation after the effect of the learning motivation variable $\left(\mathrm{X}_{2}\right)$ was removed from the linear relation between the variable of student's achievement in English subject (Y) and variable of student's perception on teacher performance $\left(\mathrm{X}_{1}\right)$. Next, at the part correlation between student's perception on teacher performance variable $\left(\mathrm{X}_{1}\right)$ towards student's achievement in English subject $(\mathrm{Y})$ is 0.238 , after the effect of learning motivation variable $\left(\mathrm{X}_{2}\right)$ was removed from student's perception on teacher performance variable $\left(\mathrm{X}_{1}\right)$.

Also, it showed that the correlation between learning motivation variable $\left(\mathrm{X}_{2}\right)$ towards student's achievement in English subject $(\mathrm{Y})$ is 0.483 . It means the correlation degree is sufficient. Then, the score of a partial correlation coefficient seems smaller. It is 0.419 . This number is the score of correlation coefficient after the effect of student's perception on teacher performance variable $\left(\mathrm{X}_{1}\right)$ was removed from the linear relationship between the variable of student's achievement In English subject (Y) and variable of learning motivation $\left(\mathrm{X}_{2}\right)$. Next, at the part correlation between the learning motivation variable $\left(\mathrm{X}_{2}\right)$ towards student's achievement in English subject (Y) is 0.383, after the effect of student's perception on teacher performance variable $\left(\mathrm{X}_{1}\right)$ was removed from learning motivation variable $\left(\mathrm{X}_{2}\right)$.

From the explanation above, it showed that both independent variables have a significant effect. Consistently, by regression analysis, the learning motivation variable is higher than the student's perception of teacher performance. It can be seen at the statistic number of partial correlation and part correlation.

\section{Coefficient of Determination (Contribution)}

Student's perception of teacher performance variable $\left(\mathrm{X}_{1}\right)$ and learning motivation variable $\left(\mathrm{X}_{2}\right)$ can determine student's achievement in English subject $(\mathrm{Y})$ in the amount of 31.3 percent $\left(\left(\mathrm{R}^{2}=0.313\right)\right.$. This coefficient of determination consists of the contribution from $\mathrm{X}_{1}$ and $\mathrm{X}_{2}$. The amount of contribution can be counted by using the formula as below:

$$
\begin{array}{ll}
\mathrm{R}_{Y . X 1 X 2} & =\mathrm{R}_{Y . X 1}+\mathrm{R}_{Y . X 2} \\
\mathrm{R}_{Y . X 1} & =\text { Beta }_{1} \times \text { koef.korelasi } \mathrm{YX}_{1}=0.29 \times 0.41=0.12 \\
\mathrm{R}_{Y . X 2} & =\text { Beta }_{2} \mathrm{x} \text { koef.korelasi } \mathrm{YX}_{2}=0.40 \times 0.48=0.19
\end{array}
$$




\section{INFERENCE: Journal of English Language Teaching}

Vol. 3, No. 2, August - November 2020

p-ISSN: 2615-8671

e-ISSN: 2615-868X

Based on the calculation above, it means this value contributes significantly to student's perceptions of teacher performance $\left(\mathrm{X}_{1}\right)$ towards student's achievement in English subject $(\mathrm{Y})$ by partial is $0.12 \%$, and the contribution of learning motivation $\left(\mathrm{X}_{2}\right)$ towards student's achievement in English subject (Y) by partial is $0.19 \%$.

\section{Conclusions}

Based on the results of hypothesis testing and discussion of research findings, some conclusions of this research can be presented as follows:

1. There are no significant effects of students' perception on teacher performance and learning motivation towards students' achievement in English subject at Private Junior High Schools in Indramayu Regency. It is proved by the score of Sig. $0.000<0.05$ and $\mathrm{F}_{\text {observed }}=49.077$.

2. There is a significant effect of students' perception on teacher performance towards students' achievement in English subject at Private Junior High Schools in Indramayu Regency. It is proved by the score of Sig. $0.000<0.05$ and $\mathrm{t}_{\text {observed }}=5.009$.

3. There is a significant effect of learning motivation towards students' English achievement in English subject at Private Junior High Schools in Indramayu Regency. It is proved by the score of Sig. $0.000<0.05$ and $\mathrm{t}_{\text {observed }}=6.773$.

This research shows that there is an effect of students' perception on teacher performance and learning motivation jointly towards students' achievement in English subject, partially, based on $t_{\text {observed }}$ statistics, the variable of students' perception of teacher performance has Sig. $0.000<0.05$ and $\mathrm{t}_{\text {observed }}=5.009$ whereas variable of learning motivation has Sig. $0.000<0.05$ and $\mathrm{t}_{\text {observed }}=6.773$. It can be seen that the learning motivation variable has a higher score of $\mathrm{t}_{\text {observed }}$ than student's perception of teacher performance. It means the learning motivation variable has a more significant effect than students' perception of teacher performance towards students' achievement in English.

\section{References}

Agustina, Djasmi, S., \& Suntoro, I. (2006). Pengaruh kepemimpinan kepala sekolah iklim kinerja guru terhadap mutu pendidikan Lampung Tengah. Jurnal Manajemen Mutu Pendidikan, 4(1), 1-16. https://core.ac.uk/download/pdf/294884706.pdf

Baharuddin, B., \& Zakaria, R. (2018). Pengaruh kecerdasan spiritual terhadap peningkatan kinerja guru di SMA Negeri 3 Takalar Kabupaten Takalar. Idaarah: Jurnal Manajemen Pendidikan, 2(1), 1-10. https://doi.org/10.24252/idaarah.v2i1.5071

Brophy, J. E. (2013). Motivating students to learn. Routledge.

Emda, A. (2017). Kedudukan motivasi belajar siswa dalam pembelajaran. Lantanida Journal, 5(2), 1721782. https://doi.org/10.22373/lj.v5i2.2838

Irianto, J. (2011). Manajemen Sumber Daya Manusia Sektor Publik di Indonesia : Pengantar Pengembangan Model MSDM Sektor Publik. Jurnal Kebijakan Dan Administrasi Publik.

Kusuma, C. S. D. (2017). Pentingnya guru dalam pengembangan minat belajar bahasa Inggris. Efisiensi: Kajian Ilmu Administrasi, 13(2), 66-84. https://doi.org/10.21831/efisiensi.v13i2.11677

Lestari. (1999). Menumbuhkan Motivasi Belajar Anak. Bhrata Karya Aksara.

Lin, L.-C. (2012). Measuring adult learners' foreign language anxiety, motivational facors, and achievement expectations: A comparative study between Chinese as a second-language students and English as a second-language students [Cleveland State University]. https://etd.ohiolink.edu/apexprod/rws_olink/r/1501/10?clear=10\&p10_accession_num=csu1355861 939

Metimukarrama, M. (2018). How students perceive the ideal teachers of English: A descriptive-reflective study at Senior High School in Pangkep Regency. SELTICS, 1(1 SE-Articles), 39-52. https://ejournals.umma.ac.id/index.php/seltics/article/view/56

Mulyasa. (2007). Standar kompetensi dan sertifikasi guru. Rosdakarya. https://rosda.co.id/pendidikankeguruan/382-standar-kompetensi-dan-sertifikasi-guru.html

Orhan Özen, S. (2017). The Effect of Motivation on Student Achievement. In E. Karadag (Ed.), The 
Factors Effecting Student Achievement: Meta-Analysis of Empirical Studies (pp. 35-56). Springer International Publishing. https://doi.org/10.1007/978-3-319-56083-0_3

Schunk, D. H., Meece, J. R., \& Pintrich, P. R. (2014). Motivation in education: Theory, research, and application (4th ed.). Pearson Education.

Sinambela, L. P. (Prof. D. (2019). Manajemen Sumber Daya Manusia. In PT.Bumi Aksara.

Turan, Z. (2015). The evaluation of flipped classroom method and examination of its effects on academic achievement, cognitive load and motivation. In Unpublished doctoral thesis, Atatürk University, Erzurum.

Wentzel, K. R. (2014). Motivating students to learn. Routledge. https://books.google.co.id/books?id=wqnmAgAAQBAJ 